\title{
8 Mathematical Models for the Comprehension of Chemical Contamination into the Hive
}

\author{
Paolo Tremolada and Marco Vighi
}

\section{CONTENTS}

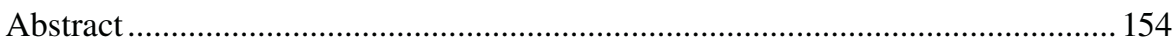

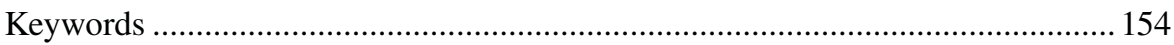

8.1 Vulnerability of Bees to Chemical Pollution: Bees as Sensitive Species....... 154

8.1.1 Chemical Contamination Sources .................................................. 155

8.1.2 Predicting Chemical Contamination with Mathematical Models...... 156

8.2 Quantification of Bees' Activities for Modeling Purposes............................ 157

8.2.1 Bee Biology: Development, Reproduction, and Renewal................... 157

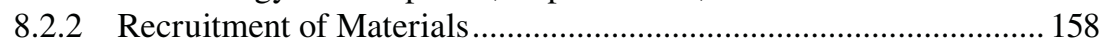

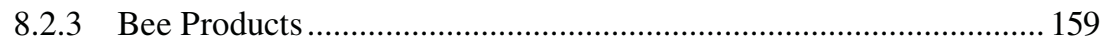

8.2.4 Environmental Parameters within the Hive …………………............. 161

8.2.5 Year Cycle of Bee Activity .............................................................. 161

8.3 Mathematical Equations for Predicting the Fate of Molecules

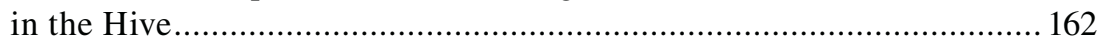

8.3.1 Partition Parameters between Hive Compartments.......................... 162

8.3.2 Quantification of Contaminant Fluxes in and out of the Hive ......... 165

8.3.3 Quantification of Intercompartment Exchanges within

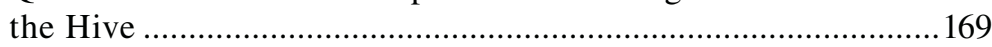

8.3.4 Non-steady-State Mass Balance of Input and Output Flows in

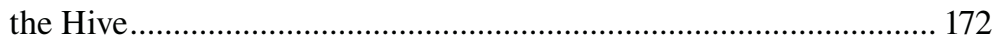

8.3.5 Application of the "Hive Model": A Case Study with the

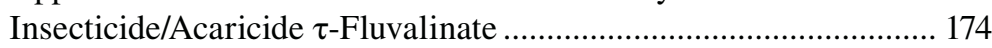

8.4 Conclusions and Future Perspectives............................................................ 175

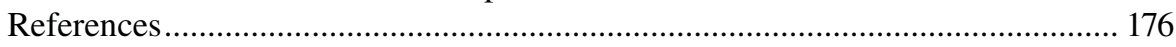




\begin{abstract}
Honey bees are very sensitive organisms, and their vulnerability toward chemical pollution is a priority environmental issue. In this chapter, the importance and the fundamental of a mathematical model able to predict the fate of chemicals in the hive are described. The "hive model" presented here is able to consider different contamination pathways: from inside the hive via pesticide treatments against bee pests or from outside by means of the eventual contamination present in nectar, pollen, resin, water, air, or vegetation. The input parameters of the model are the physical-chemical properties of the compound and the major characteristics of the hive ecosystem, from which it calculates contamination residues in bee products (honey, pollen, royal jelly, wax, and propolis) over time. The model can be applied to all nonionic chemicals with a measurable vapor pressure (volatile or semivolatile compounds). The model was validated with contamination data in bees, wax, and honey following tau-fluvalinate application in two experimental hives. The comparison between measured and modeled data over a period of 6 months was very good. Even if more experimental data should be provided for a better calibration of the model, it seems to correctly quantify the main contamination pathways from outside and within the hive.
\end{abstract}

\title{
KEYWORDS
}

Hive contamination, Pesticide, Modeling, Bee health, Bee activity

\subsection{VULNERABILITY OF BEES TO CHEMICAL POLLUTION: BEES AS SENSITIVE SPECIES}

Honey bees are considered a sensitive species indicator of environmental quality. The survival of honey bee colonies is related to the good individual performance (individual fitness) and to the efficacy of communication and cooperation between classes of bees (colony fitness). Moreover, honey bee breeding is certainly responsible for an artificial reduction of genetic diversity and for a lack of the natural selection benefits. These elements accentuate the vulnerability of honey bee colonies and their sensitivity to pollution. Since the late 1990s, widespread events of honey bee disappearance especially in the United States and in Europe (Spain, France, Italy and Germany) happened [1,2]. These events were considered alarming because it was not possible to relate them to a specific cause. This new pathology was called colony collapse disorder (CCD) [3,4]. Recrudescence of old and new pathologies [5,6], environmental stresses, including climate change, [7] and pesticide contamination [8,9] were considered as possible causes perhaps also in association among each other. The first two adversities are related to the genotypes of honey bee colonies, and they directly reflect the vulnerability of bees toward abiotic (climate change) and biotic (parasite) stresses, while the third one is directly related to human activity in terms of chemical contamination by xenobiotics.

Neonicotinoid insecticides were indicated as a possible cause of CCD events, and this possibility is a meaningful example of how xenobiotics can affect nontarget 
species in unsuspected ways (failure of risk assessment evaluation). Neonicotinoid insecticides act on the insect nicotinic (acetylcholine) receptor (nAChR) [10], and therefore they are toxic to bees too. Iwasa et al. [11] revealed that the nitrosubstituted neonicotinoids were most toxic to honey bees with very low contact $\mathrm{LD}_{50}$ values even of $18 \mathrm{ng} \mathrm{bee}^{-1}$ as in the case of imidacloprid. Neonicotinoid insecticides are used in agriculture, mainly as a seed dressing in many crops such as corn and sunflower. Being systemic insecticides, application via seed treatment enables crop protection from soil invertebrates and sucking insects both during germination and later growth. Therefore, neonicotinoid insecticides affect pollinating insects as powder dispersion during the sowing procedures via the drill fan (pneumatic seed drills) [12-14] and through the contamination of pollen and nectar, produced by crops that have been grown from treated seeds [15].

This example demonstrates that chemical exposure may happen multiple ways, some of which are easily misunderstood. In fact, neonicotinoid insecticide exposure toward bees may happen during sowing operations, when pesticide-contaminated powders are dispersed into air, and later when the powders in air subsequently deposit on local soil and vegetation. Moreover, because of the systemic activity of these insecticides, exposure may happen during the flowering phase of plants grown from treated seeds, when contaminated pollen and nectar can be foraged by bees and other pollinator insects.

\subsubsection{Chemical Contamination Sources}

Two main contamination sources toward bees can be distinguished: a direct contamination by the distribution of pesticides inside the hive to protect honey bees from parasites and an indirect contamination by all the chemicals that involuntarily come from outside.

The direct contamination is generally known and deals with few chemicals at high concentrations, as in the case of acaricides used against the mite Varroa destructor. Wallner [16], Bogdanov [17], and Johnson et al. [2] reviewed the problem of contamination of bee products following pesticide application within the hive. Fat-soluble and stable pesticides, such as bromopropylate, coumaphos, and $\tau$-fluvalinate, are known to accumulate in wax, year by year, while fat-soluble and volatile compounds, such as essential oils, and unstable pesticides, such as amitraz, do not persist because they volatilize or degrade. On the other hand, water-soluble chemicals, such as formic acid, oxalic acid, and cymiazole, do not accumulate in wax, but they are found in honey, producing an unwanted taste.

The indirect contamination source is more complex because it deals with many chemicals generally at low concentrations. Barmaz et al. [18] developed a site-specific method for assessing risks to pollinators from pesticides used in the surroundings of a bee colony. They concluded that risk levels were very different depending on agronomic practices and crop type. The greatest risk is generally found at the beginning of the growing season for annual crops and later in June-July for permanent crops. As an example, the case of neonicotinoid insecticides highlighted how pesticides coming from outside can severely threaten honey bee survival. Another example of unsuspected contamination is the presence of 


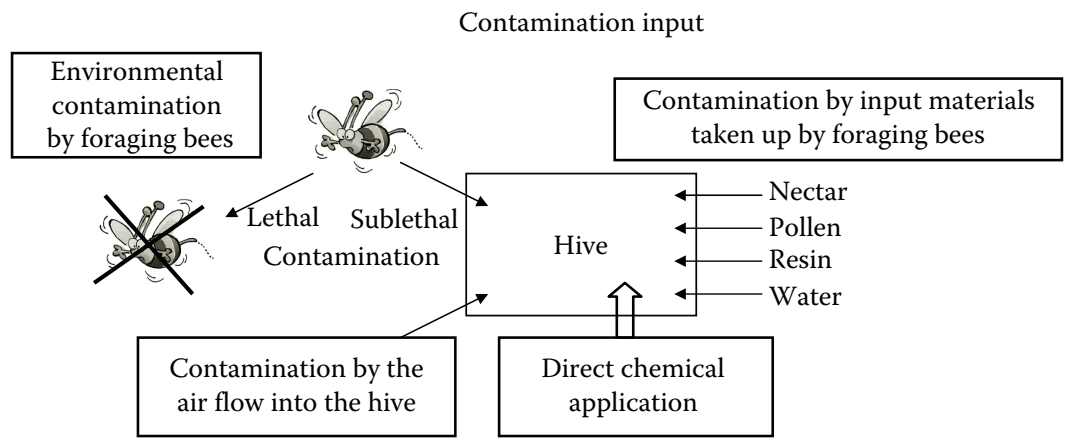

Contamination output

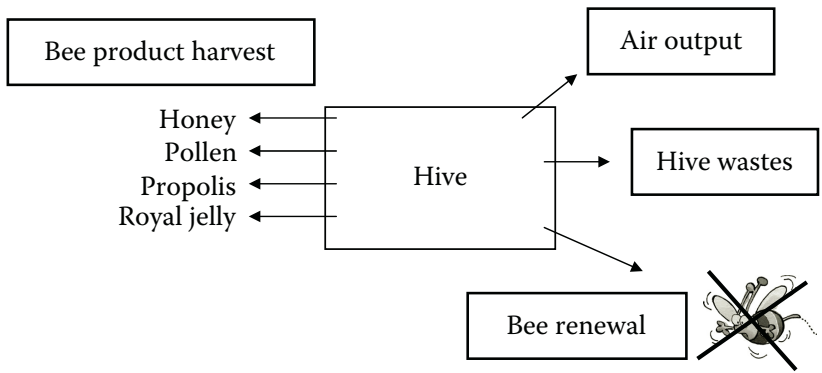

FIGURE 8.1 Schematic diagram of the main contamination sources and output ways for the hive ecosystem.

antibiotics in bee products, in the absence of direct applications to the hive. A possible explanation is the transfer of antibiotics from sewage of farms where these chemicals are extensively used for curing and preventing animal diseases. Antibiotic residues can be taken up by bees drinking sewage as water supply (bees take up sewage also in the presence of alternative cleaner water supply), and later bees can transfer antibiotics to honey bee products inside the hive. These examples highlight the complexity and the importance of the indirect contamination sources, which may affect hives in unsuspected ways. Figure 8.1 summarizes a scheme of the possible contamination sources and contamination output from the hive. Some of these pathways are well documented such as the contamination via direct pesticide application, but others were only recently considered such as those coming from pesticide-exposed pollen [19] or from environmental exposure of foraging bees $[14,18,20]$. The complexity of these multiple contamination sources and that of the system itself needs a careful description of the bee ecology in the frame of modeling applications.

\subsubsection{Predicting Chemical Contamination with Mathematical Models}

Mathematical models are useful tools for evaluating the environmental distribution and fate of chemicals [21]. Models forecast the fate of chemicals and also the 
resulting levels of exposure before their use. Moreover, they facilitate a greater comprehension of the distribution of chemicals [22]. Models based on fugacity $[23,24]$ have been extensively applied to nonionized organic chemicals at various scales: global [25], regional [26], field [27], and microecosystem [22,28,29]. These models require three types of input data: the physicochemical properties of the compounds (molecular weight, water solubility, vapor pressure, and partition coefficients), the emission patterns (amounts emitted, space and time distribution of emissions), and the environmental characteristics of the ecosystem (temperatures, compartment volumes and compositions, and fluxes). The quantification of these aspects in a model system is able to furnish information about the fate of a specific chemical with an error (uncertainty of the prediction) related to the simplification and the generalization introduced in the model, to the goodness of the input data and to stochastic events not included in the model. A crucial point of models is the quantification of the mass fluxes and the exchange parameters between compartments. The former explains the transfer of a contaminant in different places of the same compartment (e.g., the transfer of a pesticide by the air flux from outside to inside) and the second indicates the transfer from one compartment to another (e.g., the transfer of a pesticide from stored honey into cell wax or vice versa). In fugacity models, these transport parameters are described as advection parameters (mass time ${ }^{-1}$ ) and as a mass transfer coefficient (mass surface ${ }^{-1}$ time $^{-1}$ ). For applying them to the hive ecosystem, it is necessary to describe carefully and quantitatively bee activities and material fluxes.

\subsection{QUANTIFICATION OF BEES' ACTIVITIES FOR MODELING PURPOSES}

Productive honey bees and natural colonies present many substantial differences. Information reported here refers to typical productive honey bee colonies of Apis mellifera ligustica because the goal of this modeling application is the prevention of the contamination of bee products in relation to food safety. However, the same scheme can be applied to natural hives modifying the quantitative parameters when necessary. An extensive description of natural bee characteristics is reported by Seeley [30], while that of productive honey bees is reported by Chauvin [31], Grout [32], Snodgrass [33], Root [34], and Goodman and Fisher [35]. In addition, remaining information was taken from personal communications with bee experts.

\subsubsection{Bee Biology: Development, Reproduction, and Renewal}

Bee development passes through egg, larval, and adult stages. Egg deposition begins in January-February with around 1,000 eggs. Later, this number soars to a peak of 30,000-40,000 in May-June and finally declines gradually throughout the remainder of the summer, ceasing in September-October. Hatching happens 3 days after deposition, and the larval development completes in 21 days in the wax cells. Larval dimensions range from $1.5 \mathrm{~mm}$ (near the egg size) to the size of the cell in the final 
stage. Given a mean weight of $75 \mathrm{mg}$ and an approximate volume of $90 \mathrm{~mm}^{3}$ (1/4 of the cell volume), the density of larvae is about $0.83 \mathrm{mg} \mathrm{mm}^{-3}$. Brood rearing begins in late winter with around $75 \mathrm{~g}$ of brood (nearly 1,000 cells containing brood). Later, brood rises to about $2.5 \mathrm{~kg}$ (30,000-40,000 larvae) in May-June and finally declines gradually until October. The total brood production is $15 \mathrm{~kg} \mathrm{year}^{-1}$ (corresponding to 200,000 larvae).

Adult bees are specialized for different tasks depending on their sex and age. The majority of bees are sterile females (worker bees, ranging in number from 10,000 in winter to 50,000 or even 100,000 in June). Worker bees $0-2$ days old clean the cells (age caste I, cell cleaner); bees 2-11 days old care for the brood living in the central part of the nest (age caste II, broodnest caste); bees 11-20 days old constitute a food-storage caste, whose tasks occur in the peripheral, foodstorage region of the nest and that are able to produce wax (age caste III); and bees 20 days old or more become forager bees whose work is mostly outside the nest (age caste IV). Approximately $20 \%$ of forager bees spend a day or two serving as guards at the nest entrance (guard bees). The biological cycle of worker bees varies from 40 to 45 days in summer to 6 months or more in winter. The mean dimensions of a worker bee are $12-13 \mathrm{~mm}$ in length, $4 \mathrm{~mm}$ in width, and $130 \mathrm{mg}$ in weight. Given a volume of approximately $160 \mathrm{~mm}^{3}$, the density of a bee is about $0.8 \mathrm{mg} \mathrm{mm}^{-3}$.

Male bees are intermediate in size between workers and the queen. They are much less numerous than worker bees (numbering between 1,000 and 5,000 depending on the period) and are important in reproductive activity with the queen, in hive thermoregulation, and in food exchange and transport within the hive. From a quantitative point of view, they have a limited impact consisting of around $10 \%$ of the sterile females.

\subsubsection{Recruitment of Materials}

Bees may explore about 300 ha of territory daily (with a foraging radius from 1 to more than $5 \mathrm{~km}$ ) searching for food resources. Bees need only four resources for their subsistence: nectar, pollen, water, and resin. The average amounts collected yearly by a colony are $240,30,10$, and $0.1 \mathrm{~kg}$, respectively, for nectar, pollen, water, and resin. Nectar is the base material for honey production. Nectar and honey are $20 \%-40 \%$ and $80 \%$ sugar solutions, respectively. Honey has a density of $1.39-1.43 \mathrm{~kg} \mathrm{dm}^{-3}$ [36]. Water is gathered for diluting honey for brood food and for evaporative cooling of the nest on hot days. Resins are the base materials for the production of propolis, which is composed of roughly $70 \%$ resin, $25 \%$ beeswax, and $5 \%$ volatile oils. Resins are taken from trees and carried home in pollen baskets. Propolis serves to plug unwanted openings and for hygienic purposes because of its antimicrobial and antifungal activity [37].

Another important material needed by bees is oxygen. Inside the hive, thermoregulation and other bee activities require a large energy supply and create great oxygen demand. The overall oxygen consumption of a hive has been quantified as $30 \mathrm{~kg}$ year ${ }^{-1}$ with the production of $52 \mathrm{~kg} \mathrm{year}^{-1}$ and $34 \mathrm{~kg} \mathrm{year}^{-1}$ of $\mathrm{CO}_{2}$ and $\mathrm{H}_{2} \mathrm{O}$, respectively. The yearly amount of materials collected by bees is reported in Figure 8.2a. 


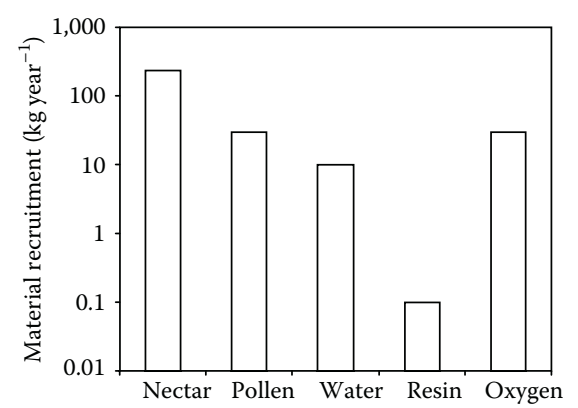

(a)
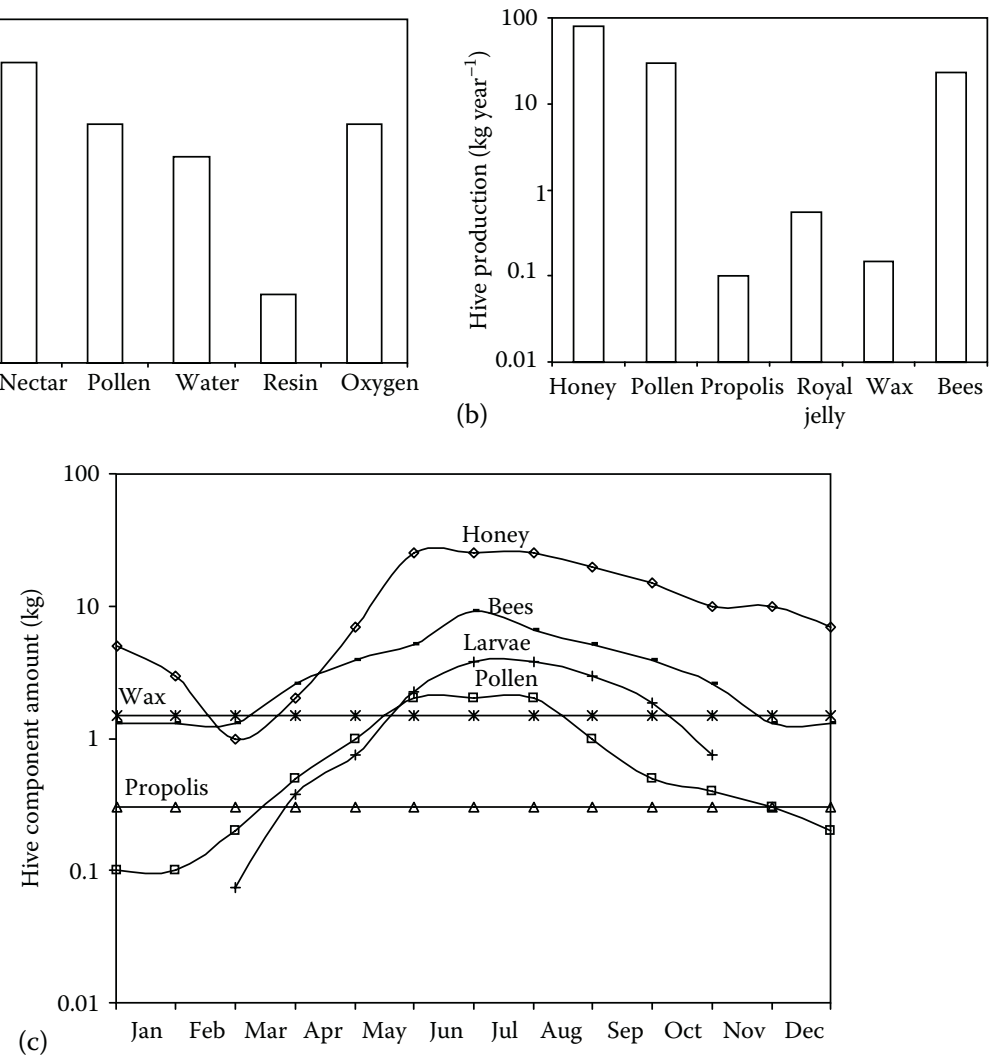

FIGURE 8.2 (a) Quantification of the material recruitment, (b) quantification of the hive products, and (c) year trends of the average amounts of hive compartments. All graphs are in logarithmic scale.

Nectar, pollen, and oxygen are the most abundant recruited materials, then water is highly requested when metabolic and nectar water are not sufficient. Resin is collected at a very low level.

\subsubsection{Bee Products}

Bees collect or produce six major products: honey, pollen, propolis, royal jelly, wax, and bees themselves (larval production). The typical honey reserve in summer is $15 \mathrm{~kg}$, and the total amount produced in a year is about $80 \mathrm{~kg}$, of which $60 \mathrm{~kg} \mathrm{year}^{-1}$ is consumed for colony maintenance ( $25 \mathrm{~kg}$ in winter and $35 \mathrm{~kg}$ in summer) and $20 \mathrm{~kg} \mathrm{year}^{-1}$ is typically removed by the beekeeper. Pollen is carried to the hive and stored by mixing the dry pollen grains with liquid (honey, nectar, or both). Pollen is generally composed of $10 \%-20 \%$ water, $10 \%-35 \%$ proteins, $15 \%-40 \%$ sugars, and $1 \%-10 \%$ lipids. The typical pollen reserve in summer is $2 \mathrm{~kg}$, and the total amount foraged in a year is $30 \mathrm{~kg}$. Honey and pollen are the primary food sources; honey furnishes energetic support and pollen supplies proteins, vitamins, fats, and minerals. 
Daily food consumption depends on age and bee activity. The daily food intake of larvae ranges from a few milligrams in the initial days to tens of milligrams during the final stage. During the first 3 days, larvae are fed with about $3 \mathrm{mg} \mathrm{day}^{-1}$ of royal jelly. Later, the larval food changes in composition based on age. However, in order to define a mean value for the full larval period, we assume consumption of $12 \mathrm{mg} \mathrm{day}^{-1}$ of larval food composed of $50 \%$ honey and $50 \%$ pollen. An adult bee consumes food in proportion to its activity. During flight, about $6.77 \mathrm{mg}$ of sugar is consumed per hour. Because a foraging bee is able to carry $10-20 \mathrm{mg}$ and $40-60 \mathrm{mg}$ of pollen and nectar, respectively, bees must make efficient choices of the most promising foraging areas in order to optimize the cost-benefit balance. We assume an average consumption of $10 \mathrm{mg} \mathrm{day}^{-1}$ of honey and $1 \mathrm{mg} \mathrm{day}^{-1}$ of pollen for adult bees. Propolis is used as an antiseptic agent and is a permanent material of the hive system present in variable amounts depending on the needs of the hive. We assume an average quantity of $0.3 \mathrm{~kg}$ with a renewal rate of $0.1 \mathrm{~kg} \mathrm{year}^{-1}$. Royal jelly is used for high-quality nutrition (queens and first-stage larvae) and is not stored in the hive but produced upon demand. We estimate an overall annual consumption of about $0.55 \mathrm{~kg}$ (10 and $540 \mathrm{~g}$ for the queen and larvae, respectively). These values are based on an average daily consumption of 20 and $1 \mathrm{mg}$ for the queen and larvae, respectively. The queen (one individual) consumes this amount daily almost all year, while larvae (180,000 reared individuals) consume this amount for 3 days only. Royal jelly is generally composed of $57 \%-70 \%$ water, $6.4 \%-17 \%$ proteins, $6.8 \%-20 \%$ sugars, $1.3 \%-7.1 \%$ of lipophilic substances (phospholipids, sterols, phenols, fatty acids, glycerides, and waxes), and $0.75 \%-1.1 \%$ minerals and other minor constituents and has a mean density of $1.1 \mathrm{~g} \mathrm{~cm}^{-3}$ [38]. Wax is the structural material of the hive, and its quantity is nearly constant throughout the year. The average quantity of wax is $1.5 \mathrm{~kg}$, most of it remaining for a long time. Bees further minimize the need of new wax by constantly recycling it. New wax is produced in abundance when a colony needs additional storage space for a large crop of honey. Bees continuously remove part of the wax (uncapping activity) and rebuild it (capping, fixing, and rebuilding activities). The amount of newly produced wax can be evaluated yearly based on the amount of cap wax $(0.15 \mathrm{~kg})$. The surface area of the wax cells (empty or full) can be evaluated by multiplying the internal surface area of one cell $\left(360 \mathrm{~mm}^{2}\right)$ by the total number of cells $(100,000)$. The resulting surface area of the wax cells is $36 \mathrm{~m}^{2}$. The exchange surface of honey, pollen, and brood is equivalent to the proportion of the wax surface occupied by each component.

A colony is able to rear up to 200,000 bees annually (including 5,000-20,000 males and a few queens), consuming a total of $20-26 \mathrm{~kg}$ of pollen (130 mg of pollen are required to produce an adult bee) and 20-30 kg of honey (one honey cell is necessary to rear several larvae). A typical nest contains about 100,000 cells with 415 cells $\mathrm{dm}^{-2}$ on each side of the comb. Each hexagon-shaped cell typically has a perimeter of $18 \mathrm{~mm}$ and an area of $24 \mathrm{~mm}^{2}$, and the wall-to-wall distance is $5 \mathrm{~mm}$. Cell depth is variable; considering a depth of $15 \mathrm{~mm}$ and an area of $24 \mathrm{~mm}^{2}$, the volume of a typical cell is about $360 \mathrm{~mm}^{3}$. Root [34] reports cell volumes varying from 360 to $192 \mathrm{~mm}^{3}$ depending on cell density (650-1,050 cells dm $\mathrm{dm}^{-2}$ for both sides of the comb). In summer, two- to three-fifths of the cells are filled with brood, twofifths with honey, and less than one-fifth with pollen. A typical nest is arranged in 
10 combs, each with external dimensions of $47 \times 30 \mathrm{~cm}$ and wax foundation dimensions of $44 \times 27 \mathrm{~cm}$, giving a total surface area of $2.4 \mathrm{~m}^{2}$. Cell walls and bases have only $0.073 \pm 0.008$ and $0.176 \pm 0.028 \mathrm{~mm}$ of wax thickness, respectively. Based on these dimensions, rapid diffusion of pollutants is expected. The combs are composed of a total of about $1.4 \mathrm{dm}^{3}(1.35 \mathrm{~kg})$ of wax. With the cap wax $(0.15 \mathrm{~kg})$, the total amount of wax in a typical nest is about $1.5 \mathrm{~kg}$. Wax is a complex blend of straight-chain monohydric alcohols esterified with carboxylic acids and hydroxycarboxylic acids mixed with various straight-chain alkanes. The density of wax is $0.958-0.970 \mathrm{~kg} \mathrm{dm}^{-3}$.

The year amounts of bee products are shown in Figure 8.2b. Honey and pollen are produced in high amounts together with bees, and much lower levels are necessary for wax and royal jelly. Production of propolis is very low.

\subsubsection{Environmental Parameters within the Hive}

Environmental conditions within the hive are quite peculiar. In the proximity of brood, bees maintain a constant temperature between $34.5^{\circ} \mathrm{C}$ and $35.5^{\circ} \mathrm{C}$ also in winter. Far from brood or in its absence, temperatures fluctuate. In winter, bees are able to maintain near $20^{\circ} \mathrm{C}$ around them using metabolic heat. The high temperatures in the brood nest accelerate the diffusion of contaminants within the hive. The intense exchange activity of bees for food supply and social communication further increases the distribution of any contaminants that may be present.

Another important parameter is the air flux into the hive for thermoregulation and for oxygen supply. The oxygen request $\left(30 \mathrm{~kg} \mathrm{year}^{-1}\right)$ corresponds to an air flux of $150 \mathrm{~m}^{3}$ year $^{-1}$. Considering that the air volume inside the hive is about $0.2 \mathrm{~m}^{3}$, the daily air flux $\left(0.4 \mathrm{~m}^{3} \mathrm{day}^{-1}\right)$ results in a twice-daily exchange of the full air volume.

\subsubsection{Year Cycle of Bee Activity}

An indicative quantification of the year cycle of the hive compartments is reported in Figure 8.2c. Throughout the year, some materials are almost permanent (wax and propolis), while others are highly variable such as food storages that reach their minimum in January-February. Larvae and adult bees start to increase from February (1,000 larvae and 10,000 adult bees) until June (30,000-40,000 larvae and 50,000-100,000 adult bees), and then they decline until October when brood rearing stops. These numbers can be transformed in mass and volume data by means of the mean weight and density of each stage. In February foraging activity starts again, and storages of pollen and honey rise slowly from 0.1 and $1 \mathrm{~kg}$, respectively, in February until 2 and $25 \mathrm{~kg}$ in May-June when they reach their maximum. Royal jelly is almost absent as storage material, but it is produced upon request for the queen and for few-day-old larvae. From August, food storage slowly declines because of the reduction in environmental availability (daily flux into the hive), while the daily consumption is still high because of the high numbers of adult bees and larvae. From August, adult bees and larvae decrease, and brood rearing ceases in October. From this moment, only adult bees are present in the hive surviving as individuals from October to February and consuming mainly 
stored food (winter storage of honey) for themselves and for the next generation reared in February.

Throughout the year, wax and propolis can be considered substantially constant, while bees, larvae, honey, and pollen change, depending on the hive conditions and on the season. In order to simplify their variability, which is hive- and year-specific, a general parabolic trend depending on the season was chosen for each compartment. Therefore, the following second-order equations in function of the number of days $(x)$ from January 1 were proposed for describing quantitatively the year trend of these compartments:

$$
\begin{gathered}
\text { Bees }(\mathrm{kg})=-0.0002 \cdot x^{2}+0.0752 \cdot x+0.3 \\
\text { Larvae }(\mathrm{kg})=-0.0002 \cdot x^{2}+0.070 \cdot x-2.6 \\
\text { Honey }(\mathrm{kg})=-0.007 \cdot x^{2}+0.27 \cdot x \\
\text { Pollen }(\mathrm{kg})=-0.00006 \cdot x^{2}+0.0214 \cdot x
\end{gathered}
$$

These equations predict compartment dimensions with $R^{2}$ values of $0.71,0.80,0.70$, and 0.68 for bees, larvae, honey, and pollen, respectively, referring to the 12 indicative data reported in Figure 8.2c. Larvae amount is 0 from November 1 to the middle of February and then follows predictions of Equation 8.2. By these equations and considering constant wax, propolis, and air compartments, the main hive components can be quantitatively described throughout the year on a day basis. The mass unit of Equations 8.1 through 8.4 can be transformed to a volumetric unit by means of their densities.

\subsection{MATHEMATICAL EQUATIONS FOR PREDICTING THE FATE OF MOLECULES IN THE HIVE}

\subsubsection{Partition Parameters between Hive Compartments}

In the hive, several compartments are quite persistent: first of all, the wax one is almost permanent, and only a small fraction is ex novo built or re-elaborated by bees, especially when stored food is deposited or consumed (capping and uncapping activities). Honey and pollen are also stored inside wax cells for months, and larvae itself stay within their cells for the time of their development (21 days). These quite long periods make possible a consistent transfer of contaminants between compartments by diffusion following the concentration gradient and the partition characteristics of the compound. The time to reach equilibrium by diffusion is generally long and depends on the media (viscosity), molecular characteristics, diffusion length (thickness), and temperature. In the case of several hive compartments, their thickness is very thin (e.g., cell walls), the time for partitioning is quite long, and the temperature 
is high (near $35^{\circ} \mathrm{C}$ ). These conditions facilitate consistent contaminant exchanges by diffusion, toward equilibrium conditions. Wallner [16] experimented over a 30-day period a consistent transfer of coumaphos residue from wax to honey. From these data and from others, reporting concentration measurements in honey and wax after a certain time from the pesticide application, experimental wax/honey partition coefficients $\left(K_{w h}\right)$ were calculated supposing that near-equilibrium conditions were present. Tremolada et al. [28] reported mean $\log K_{w h}$ of $2.7 \pm 0.66,2.7 \pm 0.50,3.2 \pm 0.95$, and $2.8 \pm 0.72$ for coumaphos, malathion, fluvalinate, and bromopropylate, respectively. As wax is a hydrophobic material and honey a hydrophilic sugar solution, $K_{w h}$ is comparable to $K_{o w}$ (octanol/water partition coefficient), but a direct correlation was not attempted, because of the variability and the scarcity of the experimental data. Waiting for a more extensive experimental data set, these authors calculated $K_{w h}$ by a theoretical approach, using fugacity. In this way, a partition coefficient (the mass ratio of a compound in two phases at equilibrium) is equal to the ratio between the capacity of the two compartments, intended as the amount of a compound that is retained by the unit of volume at the same fugacity (equilibrium condition). The unit of capacity is mol m${ }^{-3} \mathrm{~Pa}^{-1}$ and its symbol is $Z_{i}$. Therefore, $K_{w h}$ was calculated as $Z_{\text {wax }} / Z_{\text {honey }}$ where the fugacity capacity of wax $\left(Z_{\text {wax }}\right)$ was calculated throughout $K_{o c}$ (organic carbon/water partition coefficient) and that of honey $\left(Z_{\text {wax }}\right)$ throughout the capacity of water to which an additional capacity was added, for taking into account that honey has an extractable lipid residue of $0.02 \%$ on fresh weight:

$$
\begin{gathered}
Z_{w a x}=\frac{K_{o c} o c f_{w a x} \rho_{w a x}}{H} \\
Z_{\text {honey }}=Z_{\text {water }} \cdot 0.9998+Z_{\text {wax }} \cdot 0.0002
\end{gathered}
$$

where

$Z_{\text {water }}$ is equal to $1 / H$;

$H$ is Henry's law constant in $\mathrm{m}^{3} \mathrm{~Pa} \mathrm{~mol}^{-1}$; and

$K_{o c}$ is the organic carbon/water partition coefficient calculated by the relationship $\log K_{o c}=\log K_{o w}-0.21$.

The organic carbon fraction of wax $\left(o c f_{\text {wax }}\right)$ was approximated to 0.57 , and the density of wax $\left(\rho_{\text {wax }}\right)$ was fixed to $0.97 \mathrm{~g} \mathrm{~cm}^{-3}$, according to literature indications. Predicted $\log K_{w h}$ values for coumaphos, malathion, fluvalinate, and bromopropylate were in the range of 2.7 and 3.2 as the experimental ones. Using these partition coefficients and their $Z$-values and adding to them the air compartment $\left(Z_{\text {air }}=1\right.$ / $R T$, where $R=$ gas constant, $8.314 \mathrm{~Pa} \mathrm{~m}^{3} \mathrm{~mol}^{-1} \mathrm{~T}^{-1}$, and $T=$ absolute temperature), a level I fugacity model was proposed [28]. Based on physical-chemical properties of pesticides and on the amounts that persist in the hive 1 month after application, predicted concentrations in wax and honey of coumaphos, malathion, fluvalinate, and bromopropylate were calculated. Predicted concentrations accorded quite well with measured data [28]. According to this work, this very simple "hive model" was 
further developed [29]. These authors took into account all the compartments that are present in the hive and the materials recruited and produced by bees. Nectar was considered more similar to water than honey because it is a more dilute sugar solution (20\%-40\% of sugar), and therefore it was approximated to water.

Bees and larvae were considered by their lipophilic and hydrophilic compositions, and their compartment capacity was derived by $K_{o w}$ and by that of water:

$$
Z_{\text {beellarvae }}=Z_{\text {water }} \cdot 0.7+\frac{K_{o w} \cdot l i p_{\text {beellarvae }}}{H}
$$

The extractable lipid fraction of bees and larvae ( $\left(i p_{\text {bees }}\right.$ and lip $\left._{\text {larvae }}\right)$ was evaluated in 0.02 ( $\mathrm{g}$ lipid $\mathrm{g}^{-1}$ fresh weight of animal).

Pollen and royal jelly were considered similarly taking into account their typical compositions:

$$
\begin{gathered}
Z_{\text {pollen }}=Z_{\text {water }} \cdot 0.15+\frac{K_{o w} \cdot \text { lip } p_{\text {pollen }}}{H} \\
Z_{r j}=Z_{\text {water }} \cdot 0.65+\frac{K_{o w} \cdot l i p_{r j}}{H}
\end{gathered}
$$

From literature data, the average lipid fraction of pollen and royal jelly (lip pollen and $l i p_{r j}$ ) was 0.05 and 0.04 , respectively ( $\mathrm{g}$ lipid $\mathrm{g}^{-1}$ fresh weight of product).

Propolis is mainly composed of resins (70\%) and wax (25\%); therefore it was considered analogous to wax using $K_{o c}$ :

$$
Z_{\text {propolis }}=\frac{K_{o c} o c f_{\text {propolis }} \rho_{\text {propolis }}}{H}
$$

The organic carbon fraction of propolis $\left(o c f_{\text {propolis }}\right)$ was approximated to 0.57 and its density $\left(\rho_{\text {propolis }}\right)$ to $1 \mathrm{~g} \mathrm{~cm}^{-3}$.

All these compartments were considered basically by their water and lipid content in order to represent their affinity for hydrophilic and hydrophobic compounds. At the moment, an indirect validation of these capacities is derived by their application to a case study of the fluvalinate distribution in the hive [29,39].

In order to simplify the model, several hive compartments (e.g., honey, wax, propolis) can be considered together in a multicompartment: the "bee product" one. The larvae can also be considered a bee product because they are reared by bees within the wax cells (continuous contact with wax and adult bees) and because they are fed with bee products: royal jelly first and larvae food later. Because of this common origin, their contamination can be highly dependent on that of bees, and they can be grouped together in a bulk compartment (bee products), whose capacity $\left(Z_{\text {prod }}\right)$ can be calculated by the sum of the capacities of the single components multiplied by their relative volume fraction $\left(v f_{i}\right)$ : 


$$
Z_{\text {prod }}=Z_{\text {honey }} v f_{\text {honey }}+Z_{\text {wax }} v f_{\text {wax }}+Z_{\text {pollen }} v f_{\text {pollen }}+Z_{\text {propolis }} v f_{\text {propolis }}+Z_{\text {larvae }} v f_{\text {larvae }}
$$

Among bee products, pollen is peculiar because it is transported into the hive externally in pollen baskets and then it is stored in the wax cells nearly as it was originally (the contact with bees is limited), but its residence time in wax may be long, allowing contaminant exchanges with wax by diffusion. Therefore, it was decided to group it with the other bee products.

Royal jelly is not included in this bulk compartment because it is mainly produced on request and not stored in the hive: its volume fraction can be approximated to zero. Grouping all the bee products together allows reducing much of the number of compartments that may have different fugacity. By this solution, only three distinct bulk compartments were considered (air, adult bees, and bee products), having their own bulk capacities and fugacities $\left(Z_{\text {air }}, Z_{\text {bee }}, Z_{\text {prod }}\right.$, and $f_{\text {air }}, f_{\text {bee }}$, $f_{\text {prod }}$, respectively).

Contamination sources can be different (cfr. 1.1): from the air as in the case of neonicotinoid insecticides or from bees as in the case of direct pesticide treatment into the hive. Several treatment modalities use a medium in order to deliver the pesticide into the hive (e.g., Apistan strips carrying the active ingredient $\tau$-fluvalinate). From this medium, the pesticide slowly migrates into the hive. The pesticide release depends on the medium's capacity to retain it inside, which depends on the affinity of the material to the pesticide characteristics. Because treatment media are often made of plastic materials or wood, they were modeled using $K_{o c}$ :

$$
Z_{\text {treat }}=\frac{K_{o c} o c f_{\text {treat }} \rho_{\text {treat }}}{H}
$$

The organic carbon fraction of the treatment medium $\left(o c f_{\text {treat }}\right)$ was approximated to 0.57 and its density $\left(\rho_{\text {treat }}\right)$ to $0.9 \mathrm{~g} \mathrm{~cm}^{-3}$.

\subsubsection{Quantification of Contaminant Fluxes in and out of the Hive}

Contaminants may enter the hive in four main ways as shown in Figure 8.3: by the air flux, if the contaminants are dispersed in this medium; by external food sources, if these materials are contaminated [19]; by foraging bees, if they come in contact with contaminated media $[8,18]$; and by chemical application within the hive [16]. These multiple contamination sources can be described as $D$-parameters within the framework of multicompartmental fugacity models [24]. These $D$-values are flux parameters with the unit of mol day ${ }^{-1} \mathrm{~Pa}^{-1}$, and they refer to three different processes: mass fluxes (advection $D$-values), diffusion events (exchange $D$-values), or degradation processes (reaction $D$-values). Although $D$-values refer to these different processes, they have the same units, and therefore they are directly comparable for a given system (in this case, the hive ecosystem). 
Contamination input
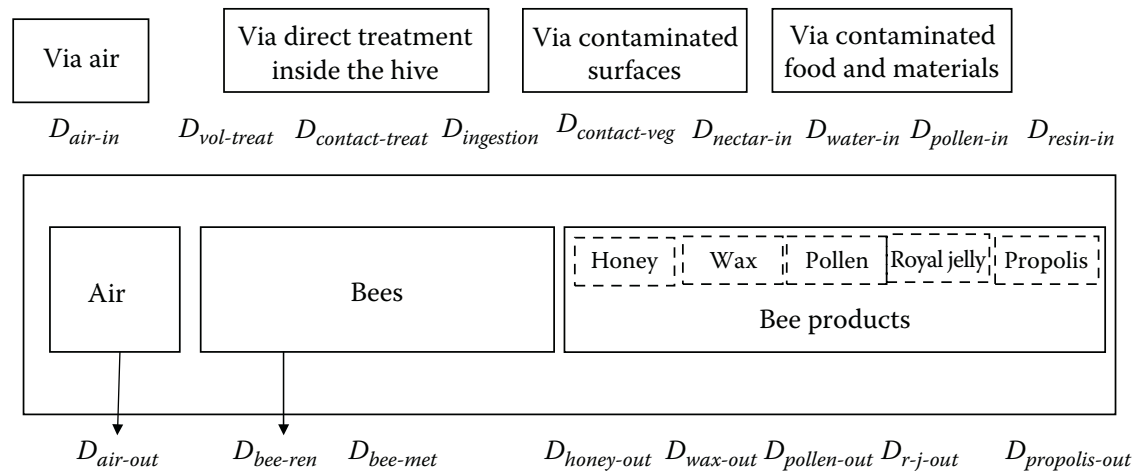

Contamination output

FIGURE 8.3 Modeling of the contaminant input and output for the hive ecosystem.

The advection of a compound by air $\left(D_{\text {air-in }}\right)$ was calculated by the air flux into the hive for oxygen supply $\left(G_{\text {air-in-out }}\right)$, which was quantified in $0.41 \mathrm{~m}^{3} \mathrm{day}^{-1}$. The outflow of air is clearly the same amount, and therefore the $D_{\text {air-out }}$ is equal to $D_{\text {air-in }}$ :

$$
D_{\text {air-in }}=D_{\text {air-out }}=G_{\text {air-in-out }} Z_{\text {air }}
$$

The contaminant inflow by this way $\left(\mathrm{mol} \mathrm{day}^{-1}\right)$ is defined by the product of the $D_{\text {air-in }}$ by the fugacity of the air out of the hive $\left(f_{\text {air-out }}\right.$ in $\left.\mathrm{Pa}\right)$, which is a function of the contaminant concentration of the outside air $\left(C_{\text {air-out }}\right.$ in $\left.\mathrm{mol} \mathrm{m}^{-3}\right)$ :

$$
f_{\text {air-out }}=\frac{C_{\text {air-out }}}{Z_{\text {air }}}
$$

The air inside the hive can be contaminated also by volatilization from the treatment medium in the case of a direct pesticide application into the hive. This advection flux $\left(D_{\text {vol-treat }}\right)$ can be calculated by diffusion, using a double-layer resistance approach with two specific mass transport coefficients $\left(M T C_{a i r}\right.$ and $M T C_{\text {treat }}$ for air and treatment-medium side, respectively). Volatilization depends also on the diffusion area $\left(A_{\text {treat }}\right)$ :

$$
D_{\text {vol-treat }}=\frac{A_{\text {treat }}}{\left(1 /\left(M T C_{\text {air }} Z_{\text {air }}\right)\right)+\left(1 /\left(M T C_{\text {treat }} Z_{\text {treat }}\right)\right)}
$$

$M T C_{\text {air }}$ and $M T C_{\text {treat }}$ were quantified in 1 and $0.0001 \mathrm{~m} \mathrm{day}^{-1}$ [29]. $M T C_{\text {air }}$ was derived from already published data [24], while that of treatment medium was $e x$ novo evaluated by the authors.

In the case of direct pesticide treatments into the hive, the contamination derives also from the contact of bees with the treatment medium or from the ingestion of the treatment solution (in the case of liquid medium, e.g., Perizim). 
The transfer of a pesticide by contact between the treatment surface and bees was evaluated by the following equation using the specific MTC $\left(M T C_{\text {treat }}\right.$ and $\left.M T C_{\text {bees-kitin }}\right)$. Both of them were considered having very low values $\left(0.0001 \mathrm{~m} \mathrm{day}^{-1}\right)$ [29]:

$$
D_{\text {contact-treat }}=\frac{A_{\text {treat }}}{\left(1 /\left(M T C_{\text {treat }} Z_{\text {treat }}\right)\right)+\left(1 /\left(M T C_{\text {bees-kitin }} Z_{\text {bees }}\right)\right)}
$$

The contact area between bees and the treatment surface $\left(A_{\text {treat }}\right)$ is roughly approximated to that of the treatment medium, but often this one is placed in between frames where a limited space is available, causing a lot of inadvertent contacts and making bee work more difficult. For this reason, bees are probably induced to reduce the strip interference, for example, by gluing them down to one frame with wax, to make for easier passage. The potential capacity of the treatment medium to release the pesticide by contact is probably constant during the treatment, but its efficacy probably declines over time because of the reduced actual contact between bees and the treatment area. This would also reduce pesticide transfer from the treatment medium to the bee compartment. Mathematically, this behavior was modeled by an exponential relationship of the contact area between the treatment medium and bees versus time $(t)\left(A_{\text {treat }}=0.012 \times e^{-1.26 \times t}\right)$. This equation was justified by experimental results of bee contamination after treatments with a pesticide acting by contact (e.g., Apistan strips). In this case, experimental concentration showed an initial contamination peak in bees during the first day after treatment followed by a slow decrease even when the treatment lasted for 1 month [39].

Another direct contamination pathway is the ingestion of the treatment solution when the pesticide application is performed by a solution/suspension. In this case, the input flow $\left(\mathrm{mol} \mathrm{day}^{-1}\right)$ was quantified by the product of the ingestion capacity of bees $\left(G_{\text {ingestion }}\right.$ in $\mathrm{m}^{3}$ day $\left.^{-1}\right)$ and the pesticide concentration in the treatment solution $\left(C_{\text {treat }}\right.$ in $\left.\mathrm{mol} \mathrm{m}^{-3}\right)$. This concentration becomes zero when the treatment ends. The ingestion capacity of bees can be calculated by multiplying the ingestion capacity of each bee (50 $\mathrm{mg}$ as in the case of a foraging bee with nectar) by the number of bees taking care of the hive $(10,000)$, assuming that the density of the pesticide suspension is about $1.0 \mathrm{~g} \mathrm{~cm}^{-3}$. The ingestion time of a single bee is rapid, but all bees cannot ingest the treatment solution simultaneously. Therefore, the overall ingestion time is much longer, on the order of many hours. In the model, $24 \mathrm{~h}$ are assumed as the time required to fill the overall ingestion capacity of bees, giving a value of $0.5 \mathrm{dm}^{3}$ day $^{-1}$ as the overall ingestion capacity $\left(G_{\text {ingestion }}\right)$.

The contamination can also be caused by the contact of foraging bees with contaminated vegetation (e.g., during pesticide spraying to agricultural crops). This advection flux $\left(D_{\text {contact-veg }}\right)$ can be modeled by diffusion between the vegetation surface and that of bees:

$$
D_{\text {contact-veg }}=\frac{A_{\text {bee }}}{\left(1 /\left(M T C_{\text {veg }} Z_{\text {treat }}\right)\right)+\left(1 /\left(M T C_{\text {bees-kitin }} Z_{\text {bees }}\right)\right)}
$$

A crucial parameter is the area of bees in contact with the vegetation. Considering that a single bee comes in contact with the plant surfaces during its foraging 
activity, Barmaz et al. [20] proposed a representative contact area of $5 \mathrm{~cm}^{2}$ bee $^{-1}$ for each foraging flight, and supposing five flights in a day, this surface became $25 \mathrm{~cm}^{2}$ bee $^{-1}$ day $^{-1}$. Multiplying this value for the number of foraging bees $(1 / 3$ of the total), the daily contact area between bees and vegetation was derived $\left(33 \mathrm{~m}^{2}\right)$. Barmaz et al. [20] suggested, as worst case, that the contamination from the vegetation surface can be calculated multiplying the contact area by the contaminant amount deposited onto the vegetation $\left(\mathrm{mol} \mathrm{m}^{-2}\right)$. In this case, the whole amount present on the vegetation surface is considered to be transferred to bees. Even if bees are protected by a chitin skeleton, which limited the contaminant uptake, they are characterized also by a thick hair cover around the body and by a wide tracheal system, which has a high capacity of gas exchanges. Respiratory surfaces can also efficiently take up gas- and particulate-phase contaminants, so that the contaminant deposited on the plant surfaces can be efficiently transferred to the bee body and absorbed via the respiratory system. Alternatively, the amount of contaminant taken up by bees from the vegetation can be calculated on the basis of a diffusion process by Equation 8.17, in which the transferred amount depends on the two MTC values $\left(M T C_{\text {veg }}\right.$ and $\left.M T C_{\text {bees-kitin }}\right)$ that were set to 0.001 and $0.0001 \mathrm{~m} \mathrm{day}^{-1}$, respectively, and in this case, the amount of contaminant taken up by bees is much more limited. Further experimental trials are necessary to clarify this contamination source.

Another input pathway is the advection of a compound inside the nest via food and materials foraged by bees. These advection parameters are defined by the following equations in which the $G$-values are the flux of materials in $\mathrm{m}^{3} \mathrm{day}^{-1}$ :

$$
\begin{aligned}
& D_{\text {nectar-in }}=G_{\text {nectar-in }} Z_{\text {nectar }} \\
& D_{\text {pollen-in }}=G_{\text {pollen-in }} Z_{\text {pollen }} \\
& D_{\text {water-in }}=G_{\text {water-in }} Z_{\text {water }} \\
& D_{\text {resin-in }}=G_{\text {resin-in }} Z_{\text {propolis }}
\end{aligned}
$$

Fluxes of nectar, pollen, water, and resin were quantified as $1.33,0.167,0.0555$, and $0.000555 \mathrm{dm}^{3} \mathrm{day}^{-1}$, respectively, and the amount of contaminant entering in the hive with these materials is defined by the product of these $D$-values by their fugacity $\left(f_{\text {nectar }}, f_{\text {pollen }}, f_{\text {water }}\right.$, and $\left.f_{\text {resin }}\right)$. These fugacities are derived from the concentrations of the contaminant in each material as shown in Equation 8.14.

The output pathways that are able to reduce the hive contamination (Figure 8.3) are those regarding the air compartment $\left(D_{\text {air-out }}\right)$ as previously defined, the bee compartment (bee renewal and bee metabolism), and the bee product compartment, in the case of collection of materials by the beekeeper.

When adult bees end their life cycle, they usually die far from the hive or, if they die inside, they are thrown out by worker bees. In this way, bee renewal causes the outflow of contaminants that were contained in the bodies of dead bees. 
This advection flux is quantified by $D_{\text {bee-ren }}$ obtained by the daily bee renewal $\left(G_{\text {bee-ren }}\right)$ of $0.142 \mathrm{dm}^{3}$ day $^{-1}$ (each bee has an individual volume of $160 \mathrm{~mm}^{3}$ and a life cycle of 45 days):

$$
D_{\text {bee-ren }}=G_{\text {bee-ren }} Z_{\text {bees }}
$$

The loss of contaminants by bee metabolism is quantified by $D_{\text {bee-met }}$, which is based on the biotransformation rate constant in bees $\left(k_{\text {bee-met }}\right.$ in day $\left.{ }^{-1}\right)$, the volume of bees $\left(V_{\text {bees }}\right.$ in $\left.\mathrm{m}^{3}\right)$, and the bee capacity $\left(Z_{\text {bees }}\right.$ in $\left.\mathrm{mol} \mathrm{m}^{-3} \mathrm{~Pa}^{-1}\right)$ :

$$
D_{\text {bee-met }}=k_{\text {bee-met }} V_{\text {bees }} Z_{\text {bees }}
$$

Contaminant removal by the material collected by the beekeeper is quantified by the terms: $D_{\text {honey-out }}, D_{\text {wax-out }}, D_{\text {pollen-out }}, D_{\text {rj-out }}$, and $D_{\text {propolis-out }}$ quantified by the corresponding $G_{\text {i-out }}$-values $\left(\mathrm{m}^{3} \mathrm{day}^{-1}\right)$ as in Equations 8.18 through 8.21. The type and amount of product withdrawals depend on the rearing practices and on the beekeeper choice; the model allows for evaluation of the contaminant output for the different alternatives in quantity and the type of materials taken out.

\subsubsection{Quantification of Intercompartment Exchanges within the Hive}

Once a pollutant reaches the hive, it can be dispersed by contact if the contamination is on the bee surface or deposited in storage cells if the contamination is within foraged materials. Wax can be contaminated directly by contact or indirectly through the cell contents. Air is in contact with bees and wax and can act as a redistribution medium inside the hive, especially for volatile compounds. Once a pollutant is stored in honey and wax, it is unlikely to degrade because these compartments are microbiologically stable. The pollutant can be recirculated when these products are used by the bees for their nutrition or for that of larvae.

Bees and air act as redistribution media with different efficacy depending on the compound properties: for example, for a low-volatile compound, contained mainly in wax, honey, or pollen, bees are the main redistribution pathway. Bees take up the contaminant when they feed on honey and pollen or when they work on wax, and they give it back when they feed the larvae or when they deposit newly secreted wax.

Considering the three compartments (air, bees, and bee products), all the exchange fluxes among them can be described by a specific $D$-value, as shown in Figure 8.4. When a given process determines the transfer of a certain amount of a contaminant from one compartment to another, this process determines an output flow for the first (giving) compartment and an input flow for the second (receiving) compartment. For example, $D_{v o l}$, which represents the pesticide volatilization from wax to air, determines an output flow from wax and an input flow to the air compartment.

For the bee compartment, the major input flows within the hive come from the consumption of contaminated honey and pollen stored in the hive $\left(D_{\text {honey-cons }}\right.$ and $D_{\text {pollen-cons }}$ ) for their feeding and for the food preparation for the larvae and the queen. In addition, bees inherit a contaminant residue from the larvae from which they are 
Contamination exchanges inside the hive

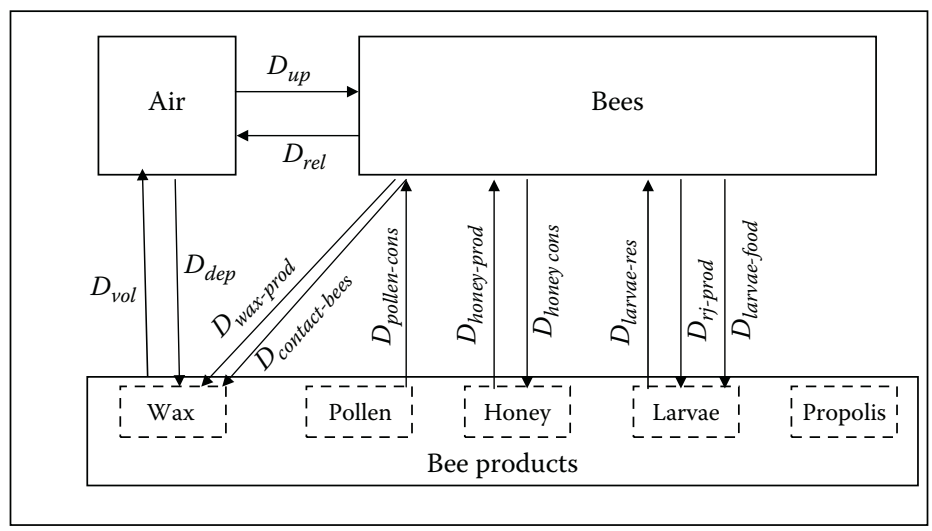

FIGURE 8.4 Modeling of contaminant exchanges within the hive ecosystem.

formed $\left(D_{\text {larvae-res }}\right)$ and uptake it from the air through the respiratory surfaces $\left(D_{u p}\right)$. These $D$-values were defined as follows:

$$
\begin{gathered}
D_{\text {honey-cons }}=G_{\text {honey-cons }} Z_{\text {honey }} \\
D_{\text {pollen-cons }}=G_{\text {pollen-cons }} Z_{\text {pollen }} \\
D_{\text {larvae-res }}=G_{\text {larvae-res }} Z_{\text {larvae }} \\
D_{\text {up }}=D_{\text {rel }}=\frac{A_{\text {bees }}}{\left(1 /\left(M T C_{\text {air }} Z_{\text {air }}\right)\right)+\left(1 /\left(M T C_{\text {bees-resp }} Z_{\text {bees }}\right)\right)}
\end{gathered}
$$

Summer honey and pollen consumption $\left(G_{\text {honey-cons }}\right.$ and $\left.G_{\text {pollen-cons }}\right)$ were estimated into 0.286 and $0.04 \mathrm{dm}^{3} \mathrm{day}^{-1}$, respectively, basing on an adult bee number of 40,000 and on an individual need of 10 and $1 \mathrm{mg} \mathrm{bee}^{-1}$ day $^{-1}$ of honey and pollen, respectively, normalized by their densities. Mean larvae flux $\left(G_{\text {larvae-res }}\right)$ of $0.0675 \mathrm{dm}^{3}$ day $^{-1}$ was calculated based on an individual volume of $90 \mathrm{~mm}^{3}$ larvae $^{-1}$, the whole larvae number produced in a year (180,000 larvae), and the production period from February to October (240 days).

The absorption and desorption from the respiratory surfaces of bees were calculated considering the respiratory surface of a single bee $\left(9.1 \mathrm{~cm}^{2} \mathrm{bee}^{-1}\right)$, the mean bee number in summer (40,000 bees), and the air- and the bee-respiratory-side MTC of 1 and $0.01 \mathrm{~m} \mathrm{day}^{-1}$, respectively, according to Mackay [24]. The respiratory surfaces of bees were evaluated indirectly knowing that the oxygen consumption of bees during flight is $5 \mathrm{~mL}$ of oxygen per hour, which corresponds to $641 \mathrm{~mL}$ of oxygen per kilogram of body weight per minute. It is known that the tracheal system and air sacs of bees are characterized by a high exchange area [33], but quantitatively this datum 
is not available. In the absence of specific data, the respiratory surface of bees was estimated by a proportion with the exchange surface able to furnish oxygen to man. During intense sporting activity, a man consumes $94 \mathrm{~mL}$ of oxygen per kilogram of body weight per minute using an oxygen exchange surface of 50-90 $\mathrm{m}^{2}$; even if this extrapolation is highly approximated, a respiratory surface of $9.1 \mathrm{~cm}^{2} \mathrm{bee}^{-1}$ was, proportionally, calculated.

The bee compartment releases the accumulated contaminant by the production of wax, honey, larvae food, and royal jelly ( $D_{\text {wax-prod }}, D_{\text {honey-prod }}, D_{\text {larvae-food }}$, and $\left.D_{r-j-p r o d}\right)$ and by the release of the compound into the air through the respiratory surfaces $\left(D_{\text {rel }}\right.$ as defined in Equation 8.27). The release of contaminants via the respiratory surface happens in the same way that absorption happens, but the net amount exchanged depends on the relative contamination levels of air and bees and thus on their fugacities.

The other contaminant released from bees through their products was quantified as follows:

$$
\begin{gathered}
D_{\text {wax-prod }}=G_{\text {wax-prod }} Z_{\text {wax }} \\
D_{\text {honey-prod }}=G_{\text {honey-prod }} Z_{\text {honey }} \\
D_{\text {larvae-food }}=G_{\text {larvae-food }} Z_{\text {larvae-food }} \\
D_{r j-p r o d}=G_{r j-p r o d} Z_{r j}
\end{gathered}
$$

The amounts of honey, wax, larvae food, and royal jelly produced daily by bees were evaluated as $0.238,0.000648,0.178$, and $0.00231 \mathrm{dm}^{3} \mathrm{day}^{-1}$, based on a total honey production of $80 \mathrm{~kg} \mathrm{year}^{-1}$, a cap wax production of $0.15 \mathrm{~kg} \mathrm{year}^{-1}$, a larvae food production of $25 \mathrm{~kg}_{\text {year }}{ }^{-1}$ of honey and $25 \mathrm{~kg}_{\text {year }}{ }^{-1}$ of pollen, and a royal jelly production of $0.61 \mathrm{~kg}$ year ${ }^{-1}$. All these year productions were divided by 8 months of activity (240 day year $\left.{ }^{-1}\right)$.

For the "bee products" compartment, the major input flows come from contact with bees $\left(D_{\text {contact-bees }}\right)$, deposition of contaminated wax, honey, larvae food, and royal jelly $\left(D_{\text {wax-prod }}, D_{\text {honey-prod }}, D_{\text {larvae-food }}\right.$, and $\left.D_{r-j-p r o d}\right)$, and deposition from the air $\left(D_{\text {dep }}\right)$. The major output flow results from the production of new bees from larvae $\left(D_{\text {larvae-res }}\right)$, from the consumption of honey and pollen $\left(D_{\text {honey-cons }}, D_{\text {pollen-cons }}\right.$, and $D_{\text {larvae-food }}$, and from the volatilization of the compound to the air compartment $\left(D_{v o l}\right)$. The majority of these input and output flows were already defined for the bee compartment. Only $D_{\text {contact-bees }}, D_{\text {vol }}$, and $D_{\text {dep }}$ were not previously defined, and they were quantified as diffusion processes starting from the overall wax surface, which is in contact with air and with bees, and from their relative MTC values:

$$
D_{\text {contact-bees }}=\frac{A_{\text {wax-bees }}}{\left(1 /\left(M T C_{\text {bees-kitin }} Z_{\text {bees }}\right)\right)+\left(1 /\left(M T C_{\text {wax }} Z_{\text {wax }}\right)\right)}
$$




$$
D_{\text {dep }}=D_{\text {vol }}=\frac{A_{\text {wax }}}{\left(1 /\left(M T C_{a i r} Z_{a i r}\right)\right)+\left(1 /\left(M T C_{w a x} Z_{w a x}\right)\right)}
$$

The wax surface in contact with air $\left(A_{w a x}\right)$ was geometrically calculated from the honeycomb surface $\left(2.4 \mathrm{~m}^{2}\right)$, while that in contact with bees $\left(A_{\text {wax-bees }}\right)$ was reduced to one-third because not all the wax surface is in contact with bees, even if the intense in-hive activities require a continuous wax-bee contact. Bee-chitin-, wax-, and air-side MTCs were set to $0.0001,0.001$, and $1 \mathrm{~m} \mathrm{day}^{-1}$, respectively.

The wax surface was approximated as that of the 10 combs $\left(2.4 \mathrm{~m}^{2}\right)$ rather than that of the wax cells $\left(36 \mathrm{~m}^{2}\right)$ because most of the cells are capped or filled with food or larvae. Therefore, the surface of wax in contact with air was approximated to the plain surface of combs, as if all the cells were capped and as if this surface was plain. These approximations were considered acceptable.

For the air compartment, the major input flows derive from the compound volatilization from wax $\left(D_{v o l}\right)$ and from the release from bees to air through the respiratory surfaces $\left(D_{\text {rel }}\right)$. The major output flow results from the deposition from air to wax $\left(D_{d e p}\right)$ and from the uptake by the respiratory surfaces of bees $\left(D_{u p}\right)$.

\subsubsection{Non-steady-State Mass Balance Of InPut and Output Flows in the Hive}

The overall balance of input and output flows among the hive compartments, which were reduced to three (bees, "bee products," and air), was described by a system of three non-steady-state mass balance equations (one for each compartment) using fugacity ( $f$, units of $\mathrm{Pa}$ ) as the unknown time-dependent variable ( $t=$ time, units of day). Non-steady-state conditions allow evaluating the evolution of the contamination within the hive after a possible contamination event. The system of ordinary differential equations describing the contamination in the three compartments is as follows:

$$
\begin{aligned}
\frac{d f_{\text {bee }}}{d t}= & \left(D_{\text {contact-treat }} f_{\text {treat }}+G_{\text {ingestion }} C_{\text {in }}+D_{\text {contact-veg }} f_{\text {veg }}+D_{\text {nectar-in }} f_{\text {nectar }}+D_{\text {water-in }} f_{\text {water }}\right. \\
& +D_{\text {honey-cons }} f_{\text {prod }}+D_{\text {pollen-cons }} f_{\text {prod }}+D_{\text {larvae-res }} f_{\text {prod }}+D_{\text {up }} f_{\text {air }}-\left(D_{\text {wax-prod }}\right. \\
& \left.\left.+D_{\text {honey-prod }}+D_{\text {larvae-food }}+D_{r j-\text { prod }}+D_{\text {rel }}+D_{\text {bee-ren }}+D_{\text {bee-met }}\right) f_{\text {bee }}\right) / V_{\text {bee }} Z_{\text {bee }}
\end{aligned}
$$

$$
\begin{aligned}
\frac{d f_{\text {prod }}}{d t}= & \left(D_{\text {pollen-in }} f_{\text {pollen }}+D_{\text {resin-in }} f_{\text {resin }}+D_{\text {contact-bees }} f_{\text {bee }}+D_{\text {wax-prod }} f_{\text {bee }}\right. \\
& +D_{\text {honey-prod }} f_{\text {bee }}+D_{\text {larvae-food }} f_{\text {bee }}+D_{r-j-\text { prod }} f_{\text {bee }}+D_{\text {dep }} f_{\text {air }} \\
& \left.-\left(D_{\text {larvae-res }}+D_{\text {honey-cons }}+D_{\text {pollen-cons }}+D_{\text {vol }}\right) f_{\text {prod }}\right) / V_{\text {prod }} Z_{\text {prod }}
\end{aligned}
$$




$$
\frac{d f_{\text {air }}}{d t}=\frac{\left(D_{\text {air-in }} f_{\text {out }}+D_{\text {vol-treat }} f_{\text {treat }}+D_{\text {vol }} f_{\text {prod }}+D_{\text {rel }} f_{\text {bees }}-\left(D_{\text {air-out }}+D_{\text {dep }}+D_{\text {up }}\right) f_{\text {air }}\right)}{V_{\text {air }} Z_{\text {air }}}
$$

where

$f_{i}$ is the fugacity with the units of $\mathrm{Pa}$;

$D_{i}$ represents the various $D$-values (advection, exchange, and degradation) with the units of mol day ${ }^{-1} \mathrm{~Pa}^{-1}$;

$V_{i}$ represents the compartment volumes with the units of $\mathrm{m}^{-3}$;

$Z_{i}$ is the compartment capacities with the units of $\mathrm{mol} \mathrm{m}^{-3} \mathrm{~Pa}^{-1}$;

$f_{\text {bee }}, f_{\text {prod }}$, and $f_{\text {air }}$ are the fugacity of the compound in bees, bee products, and air, respectively; and

$f_{\text {treat }}$ is the fugacity of the contaminant in the treatment medium determining a flux to bees by contact and to air by volatilization.

This term is considered for pesticide treatments into the hive acting by contact (e.g., Apistan), while for treatments acting by ingestion (e.g., Perizin), the pesticide input is obtained by multiplying the ingestion capacity of bees $\left(G_{\text {ingestion }}\right.$, units of $\mathrm{m}^{3}$ day $\left.^{-1}\right)$ by the pesticide concentration in the treatment solution $\left(C_{i n}\right.$, units of $\left.\mathrm{mol} \mathrm{m}^{-3}\right) \cdot f_{\text {nectar }}$ and $f_{\text {water }}$ in Equation 8.34 and $f_{\text {pollen }}$ and $f_{\text {resin }}$ in Equation 8.35 are the fugacities of contaminated nectar, water, pollen, and resin, respectively. In Equation 8.36, the term $f_{\text {out }}$ is the fugacity of the air outside the hive, if it is contaminated. These fugacity values $(\mathrm{Pa})$ can be calculated by the ratio between the concentration of the compound in each medium $\left(\mathrm{mol} \mathrm{m}{ }^{-3}\right)$ and its capacity $\left(\mathrm{mol} \mathrm{m}^{-3} \mathrm{~Pa}^{-1}\right)$ as shown in Equation 8.14.

The differential equation system exposed earlier calculates day to day the fugacities in air, bees, and "bee products" as a result of input flows toward the considered compartment ( $D$-values with positive algebraic signs) and output flows from the same compartment ( $D$-values with negative algebraic signs). Output flows can produce an input flow toward another compartment, taking the contaminant inside the hive, or, if they are addressed outside, they constitute a contaminant loss.

The contamination from outside can be derived from many pathways, each represented by a specific $D$-value multiplied by its fugacity, which represents the intensity of the contamination. The input flow is addressed to the specific compartment that initially receives the contaminant. For example, $D_{\text {nectar-in }}$ and $D_{\text {water-in }}$, which represent the eventual pesticide inputs from nectar and water, are considered as input flows only for the bee compartment, because nectar and water are effectively ingested by bees and not simply carried in external structures such as pollen baskets. These external structures are used by bees to carry pollen and resin, and the contaminants present in these materials are deposited directly into the "bee products" compartment. For this reason, $D_{\text {pollen-in }}$ and $D_{\text {resin-in }}$ are considered as input flows for the "bee products" compartment. 


\subsubsection{Application of the "Hive Model": A Case Study WITH THE INSECTICIDE/ACARICIDE $\boldsymbol{\tau}$-FluVALINATE}

The equation system reported earlier was applied to a specific contamination trial $[29,39]$. The pesticide used was $\tau$-fluvalinate, a pyrethroid insecticide/acaricide commonly used against the bee pest Varroa destructor.

Following common treatment methodologies, the pesticide was administered by two plastic strips hung between combs for 1 month. From the strips, the compound passes to adult bees principally by contact, and from them the pesticide is able to reach the other hive compartments, including larvae too, in order to protect both adult bees and larvae. If bees are contaminated with fluvalinate, they tend to produce contaminated products or to contaminate products by contact during handling. Once fluvalinate residues are transferred to bee products (wax, honey, pollen, larvae, and propolis), the products themselves become secondary sources of contamination for bees. All of these exchanges can be mathematically expressed by the differential system of Equations 8.34 through 8.36, and using the physical-chemical properties and treatment conditions of $\tau$-fluvalinate, this equation system was able to quantify the pesticide fugacity in bees, "bee products," and air, and from them, the concentrations in the different hive compartments as a function of time. Figure 8.5

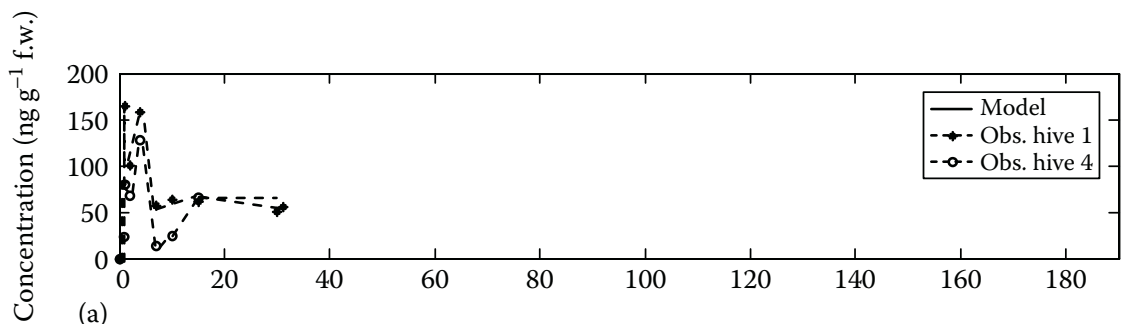

(a)

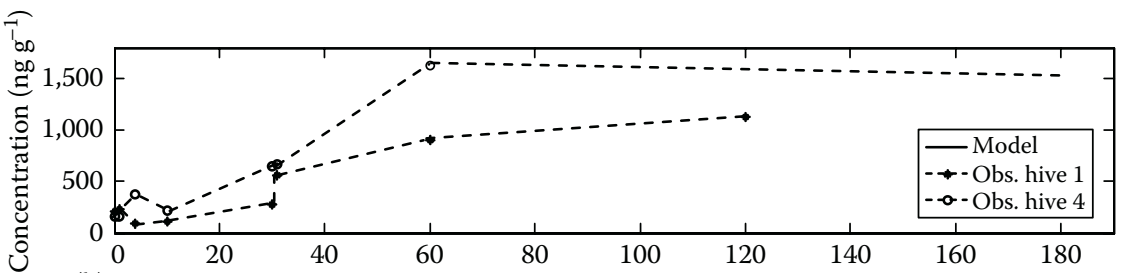

(b)

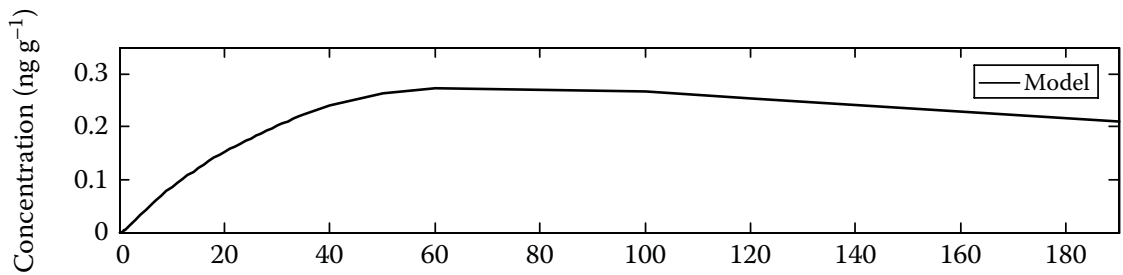

(c)

Days from treatment

FIGURE 8.5 Comparison of predicted and measured concentrations of $\tau$-fluvalinate in (a) bees, (b) wax, and (c) honey. 
reports fluvalinate concentrations in bee wax and honey predicted by the model (continuous lines), starting just before the treatment (Time 0) up to 180 days after it. Experimental data measured in the two experimental hives (hives 1 and 4) were also reported (dotted lines).

Measured concentrations in experimental hives gave consistent results between them, and the two data sets drew quite clear time trends. Bees were not contaminated before treatment; thereafter, their contamination level rose to a peak and later decreased to a nearly constant value $\left(50 \mathrm{ng} \mathrm{g}^{-1}\right.$ f.w.) until the end of the treatment (30 days). In contrast, measured concentrations in wax gradually increased after treatment, reaching a plateau slightly above $1,000 \mathrm{ng} \mathrm{g}^{-1}$ at 60 days after treatment. Measured contamination levels in honey were always below the limit of quantification of $2.5 \mathrm{ng} \mathrm{g}^{-1}$. Predicted concentrations closely follow these trends, showing predicted levels near or intermediate between measured ones. Predicted concentrations for honey were always below the limit of quantification, according to measurements.

The model predicts a rapid increase in concentration in bees just after treatment, as suggested by the measured data, which shows an initial high variability. This behavior can be explained considering that only a fraction of the bees working in the nest can simultaneously visit the treatment strips. Later, the general contamination of all hive compartments (secondary sources) and the reduced visitation of bees to the treatment strips (primary source) tend to make the concentrations in bees more uniform (as shown by measurements). Predicted data show a concentration peak in bees during the first few days of treatment and then slowly decrease because of the reduced contact between strips and bees. After 30 days, when the treatment strips are removed, concentrations in bees tend to decrease more rapidly because the primary pesticide source (the strips) is no longer present and secondary sources (contaminated hive products) remain. Predicted concentrations in wax and honey follow a slowly rising trend until about 60 days, according to the measured data. After removal of the strips, the hive products still receive the pesticide through contact with bees until their fugacity becomes equal to that of bees. Thereafter, concentrations in the hive products begin to slowly decline because, in the absence of new pesticide input, the various loss processes begin to reduce the overall contamination. Concentrations decrease more rapidly in bees than in bee products (wax and honey) because of the persistence of this pesticide in these compartments. Biotransformation and advection out of the hive by dead bees are the primary processes by which the pesticide is lost from the hive system. The slow decline of the contamination in wax is consistent with the observation of the wax contamination before the treatment, presumably derived from previous treatments at least 1 year before.

\subsection{CONCLUSIONS AND FUTURE PERSPECTIVES}

The presented "hive model" considers different contamination pathways: from outside, such as the contamination coming from nectar, pollen, resin, water, air, and vegetation, or from inside via pesticide treatments against bee pests. It includes almost all the contamination threats toward bees, but, at the moment, it has been applied successfully to only a single case. However, as any initial scientific effort, 
it can be very useful in indicating the most urgent research need. Analyzing the input data of the model, it uses the physical-chemical properties of the compound and the major characteristics of the hive ecosystem, from which it calculates contamination residues in bee products (honey, pollen, royal jelly, wax, and propolis) over time. While the physical-chemical properties of a compound are quite well known, the hive characteristics, important for contamination modeling, are much less known. Even among some well-known hive parameters, there is a certain level of uncertainty. Of course, the food consumption of adult bees depends on food availability, bee age, and primary activities: bees that are preparing royal jelly require more pollen than those that are producing new wax. However, for modeling purposes referring to an average value of food intake is sufficient, and this average value may represent the material fluxes into the hive with a sufficient detail. For this reason, the hive parameters proposed in this chapter can be considered to be sufficiently supported by the present knowledge, even if it is clear that they may be improved and corrected. On the other hand, many more uncertainties exist in the evaluation of the contaminant behavior inside the hive. For example, the compartment capacities ( $Z$-values) and the exchange parameters ( $D$-values) described in this chapter have, at the moment, only been proposed and indirectly validated with a single case study. It is clear that much more experimental work is needed for better describing them and for supporting these parameters with experimental data. For example, the capacity of chemicals to cross the chitin barrier or the diffusion velocity in wax is unknown. All these values were quantified by a specific MTC parameter defined by similarity from others already proposed. Specific experiments of volatilization from wax, honey, and pollen or bee contamination from air should be performed with more experimental data and evidence to quantify these exchange parameters. A first step could be the experimental evaluation of the wax-honey partitioning, starting from contaminated honey or wax and lasting through the chemical diffusion process until equilibrium is reached.

In the future, more experimental works could produce more experimentally based parameters, which can improve the present attempt of modeling the contamination of the hive ecosystem. A more validated "hive model" can be used in two ways: as a prognostic tool for assessing the possible contamination levels of bee products for voluntary contamination events (pesticide treatment into the hive) and as a diagnostic tool for understanding the contaminant fate of involuntary contamination events, such as those coming from outside. The "hive model" can be applied in order to test the contamination levels of different pesticides depending on their application modalities or to give unsuspected indications of severe contamination threat from outside.

\section{REFERENCES}

1. B. Hileman, Why are the bees dying? Chem. Eng. News 85 (2007), pp. 56-61.

2. R.M. Johnson, M.D. Ellis, C.A. Mullin, and M. Frazier, Pesticides and honey bee toxicity-USA, Apidologie 41 (2010), pp. 312-331.

3. D. vanEngelsdorp, R. Underwood, D. Caron, and J. Hayes, An estimate of managed colony losses in the winter of 2006-2007: A report commissioned by the Apiary Inspectors of America, Am. Bee J. 147 (2007), pp. 599-603. 
4. B. Laszlo, About the uncommon bee losses. Literature review, Magy. Allatorvosok 130 (2008), pp. 551-557.

5. M. Ribiere, V. Olivier, P. Blanchard, F. Schurr, O. Celle, P. Drajnudel, J.P. Faucon, R. Thiery, and M.P. Chauzat, The collapse of bee colonies: The CCD case ('Colony collapse disorder') and the IAPV virus (Israeli acute paralysis virus), Virologie 12 (2008), pp. 319-322.

6. M. Higes, R. Martín-Hernández, E. Garrido-Bailón, A.V. González-Porto, P. GarcíaPalencia, A. Meana, M.J. del Nozal, R. Mayo, and J.L. Bernal, Honeybee colony collapse due to Nosema ceranae in professional apiaries, Environ. Microbiol. Rep. 1 (2009), pp. 110-113.

7. Y. Le Conte and M. Navajas, Climate change: Impact on honey bee population and diseases, Rev. Sci. Tech.-OIE 27 (2008), pp. 499-510.

8. A. Decourtye, J. Devillers, S. Cluzeau, M. Charreton, and M. Pham-Delègue, Effects of imidacloprid and deltamethrin on associative earning in honeybees under semi-field and laboratory conditions, Ecotox. Environ. Safe. 57 (2004), pp. 410-419.

9. R.M. Johnson, H.S. Pollock, and M.R. Berenbaum, Synergistic interactions between in-hive miticides in Apis mellifera, J. Econ. Entomol. 102 (2009), pp. 474-479.

10. S. Buckingham, B. Lapied, H. Corronc, and F. Sattelle, Imidacloprid actions on insect neuronal acetylcholine receptors, J. Exp. Biol. 200 (1997), pp. 2685-2692.

11. T. Iwasa, N. Motoyama, J.T. Ambrose, and R.M. Roe, Mechanism for the differential toxicity of neonicotinoid insecticides in the honey bee, Apis mellifera, Crop. Prot. 23 (2004), pp. 371-378.

12. M. Greatti, A.G. Sabatini, R. Barbattini, S. Rossi, and A. Stravisi, Risk of environmental contamination by the active ingredient imidacloprid used for corn seed dressing. Preliminary results, Bull. Insectol. 56 (2003), pp. 69-72.

13. M. Greatti, R. Barbattini, A. Stravisi, A.G. Sabatini, and S. Rossi, Presence of the a.i. imidacloprid on vegetation near corn fields sown with Gaucho ${ }^{\circledR}$ dressed seeds, Bull. Insectol. 59 (2006), pp. 99-103.

14. P. Tremolada, M. Mazzoleni, F. Saliu, M. Colombo, and M. Vighi, Field trial for evaluating the effects on honeybees of corn sown using Cruiser ${ }^{\circledR}$ and Celest $x l^{\circledR}$ treated seeds, Bull. Environ. Contam. Toxicol. 85 (2010), pp. 229-234.

15. M.-P. Halm, A. Rortais, G. Arnold, J.N. Taséi, and S. Rault, New risk assessment approach for systemic insecticides: The case of honey bees and imidacloprid (Gaucho), Environ. Sci. Technol. 40 (2006), pp. 2448-2454.

16. K. Wallner, Varroacides and their residues in bee products, Apidologie, 30, (1999) pp. 235-248.

17. S. Bogdanov, Contaminants of bee products, Apidologie 37 (2006), pp.1-18.

18. S. Barmaz, S.G. Potts, and M. Vighi, A novel method for assessing risks to pollinators from plant protection products using honeybees as a model species, Ecotoxicology 19 (2010), pp. 1347-1359.

19. S. Villa, M. Vighi, A. Finizio, and G. Bolchi Serini, Risk assessment for honeybees from pesticide-exposed pollen, Ecotoxicology 9 (2000), pp. 287-297.

20. S. Barmaz, Plant protection product risk assessment: Distribution and experimental validation in terrestrial ecosystems, $\mathrm{PhD}$ dissertation, University of Milano-Bicocca, Milan, Italy, 2009.

21. C.E. Cowan, D. Mackay, T.C.J. Feijtel, D. Van de Meent, A. Di Guardo, and Davies, The Multimedia Fate Model: A Vital Tool for Predicting the Fate of Chemicals, SETAC Press, Pensacola, FL, 1995.

22. P. Tremolada, M. Sugni, G. Gilioli, A. Barbaglio, F. Bonasoro, and M.D. Candia Carnevali, A dynamic model for predicting chemical concentrations in water and biota during the planning phase of aquatic ecotoxicological tests, Chemosphere 75 (2009), pp. $915-923$. 
23. D. Mackay and S. Paterson, Finding fugacity feasible, Environ. Sci. Technol. 15 (1979), pp. 1218-1223.

24. D. Mackay, Multimedia Environmental Model, The Fugacity Model, 2nd ed., Lewis Publishers, Boca Raton, FL, 2001.

25. F. Wania and D. Mackay, A global distribution model for persistent organic chemicals, Sci. Total. Environ. 160/161 (1995), pp. 211-232.

26. D. Mackay, S. Paterson, and W.Y. Shiu, Generic models for evaluating the regional fate of chemicals, Chemosphere 24 (1992), pp. 695-717.

27. A. Di Guardo, D. Calamari, G. Zanin, A. Consalter, and D. Mackay, A fugacity model of pesticide runoff to surface water: Development and validation, Chemosphere 28 (1994), pp. 511-531.

28. P. Tremolada, I. Bernardinelli, M. Colombo, M. Spreafico, and M. Vighi, Coumaphos distribution in the hive ecosystem: Case study for modeling applications, Ecotoxicology 13 (2004), pp. 589-601.

29. P. Tremolada, I. Bernardinelli, B. Rossaro, M. Colombo, and M. Vighi, Predicting pesticide fate in the hive (part II): Development of a dynamic hive model, Apidologie 42 (2011), pp. 439-456.

30. T.D. Seeley, Honeybee Ecology. A Study of Adaptation in Social Life, D. Thomas Publisher, Princeton University Press, Princeton, NJ, 1985.

31. R. Chauvin, Traité de Biologie de l'Abeille, Masson et C, Paris, France, 1968.

32. R.A. Grout, The Hive and the Honey Bee, Dadant \& Sons, Hamilton, IL, 1973.

33. R.E. Snodgrass, Anatomy of the Honey Bee, Cornell University Press, London, UK, 1984.

34. A.I. Root, The ABC and XYZ of Bee Culture, A.I. Root Company, Medina, OH, 1990.

35. L.J. Goodman and R.C. Fisher, The Behaviour and Physiology of Bees, C.A.B. International, Wallingford, UK, 1991.

36. E. Crane, Honey. A Comprehensive Survey, William Heinemann Ltd, London, UK, 1976.

37. M.C. Marcucci, Propolis: Chemical composition, biological properties and therapeutic activity, Apidologie 26 (1995), pp. 83-99.

38. G. Lercker, M.F. Caboni, M.A. Vecchi, A.G. Sabatini, and A. Nanetti Caratterizzazione dei principali costituenti della gelatina reale, Apicoltura 8 (1992), pp. 11-21.

39. S. Bonzini, P. Tremolada, I. Bernardinelli, M. Colombo, and M. Vighi, Predicting pesticide fate in the hive (part 1): Experimentally determined $\tau$-fluvalinate residues in bees, honey and wax, Apidologie 42 (2011), pp. 378-390. 